\title{
EMBRYONIC AND LARVAL DEVELOPMENT OF THAI PANGAS PANGASIANODON HYPOPTHALMUS (SAUVAGE, 1878) UNDER HATCHERY CONDITION
}

\author{
B. K. Chakraborty ${ }^{1 *}$ and D. K. Jha ${ }^{2}$ \\ Department of Fisheries, Bangladesh and Culture of Mud Eel, Mud Crab, \\ Aquaculture and Management Centre, Mymensingh, Bangladesh
}

\begin{abstract}
The embryonic and larval development of Pangasianodon hypophthalmus was investigated during peak spawning periods (May-July 2019). The fertilized eggs were adhesive and spherical with a greenish-brown egg capsule. The yolk sac was yellowish-brown in color and $1.00-1.70 \mathrm{~mm}$ in diameter. The first cleavage stage, embryonic shield, head, tail region, neural grooves and somites were apparent after fourteen hours post-fertilization. The ranges of incubation period were from 18.00$20.00 \mathrm{hrs}$ at a temperature of $26-30^{\circ} \mathrm{C}$. The newly hatched larvae were transparent and light yellowish in color with a body length of 2.98-3.10 mm. Eye pigment appeared and the heart started to work within 12-16 hrs of hatching. The mouth became well developed at the age of $24 \mathrm{hrs}$; barbules were prominent, elongated and look like threads. The yolk sac was fully absorbed and the palatine teeth were fully increased during the 3 days pro-larval stage. The stomach became functional and aerial respiration started after 3 days of larval development. After $72 \mathrm{hrs}$, the young fry was well-developed, and appeared an adult, and length was measured up to $7.20 \pm 0.02 \mathrm{~mm}$. When daily ration of pangas larvae is insufficient cannibalism was recorded. This study must be supportive for researcher and nursery owner on the biology and ecology of the fish, which might be helpful for appropriate measure of sustainable nursery, rearing and management technology of pangas.
\end{abstract}

Key words: Embryonic development, Larval development, Blastula, Gastrula, Organogenesis, Pangasianodon hypophthalmus.

\section{INTRDUCTION}

Pangasianodon hypophthalmus is commonly known as pangas in Bangladesh, belonging to the family pangasiidae, under the order Siluriformes. According to Roberts and Vidthayanon (1991), the origin of P. hypophthalmus was from the Mekong river of Vietnam to the Chao Phraya River to Thailand and it was spread over other countries such as Malaysia, Indonesia, Bangladesh and China. David (1962) reported that Pangasius $s p$. is highly tolerant to salinity, $\mathrm{pH}$, dissolved oxygen, temperature or even pollution. This species is accepted as

*Author for corresponding: <bborty@gmail.com>; ${ }^{2}$ Agriculture and Forest University, Rampal, Nepal (C)2021 Zoological Society of Bangladesh DOI: https://doi.org/10.3329/bjz.v49i1.53690 
delicious food by a wide range of people. Because this species is a good source of protein and calorie of people in rural as well as urban areas. Pangas species have been cultured in earthen ponds and this fish is commonly known as shark catfish or pangas and attained weights of $3 \mathrm{~kg}$ within 2 years of birth (Bardach et al. 1972).

Literature on reproductive behavior of catfishes has been on spawning strategies and parental care. There is a poor information on the early developmental stages of catfish considering the large number of species and it's wide distribution. The information on the reproductive behavior and embryonic development of panga is also poor. In the cat fish world there are some studies on the supply of food and culture techniques (Zulkafli and Zahari 1989); growth, reproduction and breeding of Thai pangas (Manat et al. 1990); taxonomical and behavioral difference of $P$. sutchi and Pangasianodon gigas (Wanpen 1984); rearing of patin fry (Pangasius pangasius) in different salinity (Arifin 1990) and early embryonic development of Thai pangas (Asiful 2002). The aim of the study is to find out the early life cycle from oocyte activation to the beginning of the adult fry of pangas under hatchery conditions.

\section{MATERIAL AND METHODS}

The experiment was studied in the Satota hatchery, Trisal, Mymensingh. Embryo inherent and larvae development were observed in two trials using two pairs of male (3.5-4.5kg) and female (3-4kg) brood stocks of $P$. hypophthalmus fish. Fertilization rate was estimated according to the novel method proposed by Okomoda et al.(2017). An early developmental stage of $P$. hypophthalmus was observed upto $76.00 \mathrm{hrs}$ starting from egg fertilization.The eggs collected randomly from the hatching jar. The developing stages of $P$. hypophthalmus observed at every 5 to $10 \mathrm{mins}$ interval till completion of morula stage and then after every one-hour interval up to hatching. The eggs were kept into $70 \%$ ethanol solution for preservation for next observation. At least 15 eggs undergoing embryonic development process was studied to get accurate information. The larval samples were also collected from the hatching jar and hapa. Initial samples were collected hourly. At least ten larvae were collected and immediately put into $70 \%$ ethanol solution for further study. The collected larvae examined as soon as possible.

Early developmental stages were observed under a Stereomicroscope (Olympus, SZH10 Research Stereo). At each developing stage, ten individuals were tested for confirmation of different stages and the timing of development. All the stages of development were observed at every 5 to 10 mins interval till the completion of morula and then after every one-hour interval till completion of 
organogenesis. The sketches of every developmental stage were drawn by hand using Camera Lucida (Olympus, Japan 306681) fixed on a Stereo microscope (Olympus, SZH10 Research Stereo). Every developmental stages of fish larvae were temporarily stained with methylene blue for clear observation. Young fry were fed on freshly hatched nauplii, Artemiasalina during 1-4 days and Tubifex worms and powdered dry food during 5-14 days.

\section{RESULTS AND DISCUSSION}

This experiment was initiated to observe the developmental stage of $P$. hypophthalmus. A description of embryonic and larval development is presented in Table 1 and 2. The findings of different stages of embryonic development process of $P$. hypophthalmus were described in the table 1 .

\section{Embryonic development}

Fertilized eggs: The fertilization of eggs started as soon as the sperm enters into the eggs, almost immediately a cortical reaction closed the microphyle which denied the entry of more sperm (Barua 1990). The fertilized eggs were adhesive, sticky, demersal, and brownish-yellow in colour. After fertilization the diameter of the egg recorded at $1.00 \mathrm{~mm}$. Slight swelling was monitored after fertilization of eggs. Fertilized eggs had a spot (blastodisc) on one pole and were readily identifiable through naked eye within 15 mins of fertilization (Figs. A and B). The egg membrane is fully divided from the egg and has a small perivitelline space with fluids. This fluid cushion protects the eggs and external injury of the embryo (Khan 1972).

Two celled stage: The first cleavage of eggs recorded within 30 mins at $27.8^{\circ} \mathrm{C}$. The cleavage of eggs was partial or meroblastic, forming a transitory blastula stage. The blastodisc divided into 2 distinct cells by vertical cleavage within 0.35 hrs post fertilization (Fig. C).

Four celled stage: A second cleavage of four cells was formed within 45 mins (Fig. D). The second cleavage was at right angle to the first. Eggs measured 1.70 \pm 0.02 $\mathrm{mm}$ in diameter.

Eight celled stage: Third cleavage forming eight cells recorded after $1.10 \mathrm{hrs}$ of second cleavage at $27.3^{\circ} \mathrm{C}$ (Fig. E). The diameter of the eggs was $1.70 \pm 0.02$ $\mathrm{mm}$.

Sixteen celled stage: The sixteen cells stage was formed within 1.10 to 1.35 hrs (Fig. F). The diameter of the eggs was $1.70 \pm 0.02 \mathrm{~mm}$ 
Table 1. Summary of embryonic development process of Pangasianodon hypophthalmus

\begin{tabular}{|c|c|c|c|c|c|}
\hline Phase & $\begin{array}{l}\text { Figure } \\
\text { No. }\end{array}$ & $\begin{array}{l}\text { TAF } \\
\text { (hrs) }\end{array}$ & $\begin{array}{l}\text { Mean } \\
\text { temperature } \\
\left({ }^{\circ} \mathrm{C}\right)\end{array}$ & $\begin{array}{l}\text { Mean total } \\
\text { diameter } \\
(\mathrm{mm})\end{array}$ & Characteristics \\
\hline 1 & 2 & 4 & 5 & 6 & 7 \\
\hline Fertilized eggs & A & 0.00 & $27.8 \pm 0.02$ & $1.00 \pm 0.40$ & $\begin{array}{l}\text { Eggs adhesive and round in shape brownish, a yolk } \\
\text { composed of a deep. }\end{array}$ \\
\hline \multirow{5}{*}{$\begin{array}{l}\text { Blastolation } \\
\text { (segmentation) }\end{array}$} & B & 0.30 & $27.8 \pm 0.02$ & $1.70 \pm 0.02$ & $\begin{array}{l}\text { Start of } 1 \text { st cleavage, this controlled to small disc of } \\
\text { cytoplasm at animal pole, dividing blastodisc into two } \\
\text { blastomeres. }\end{array}$ \\
\hline & C-D & $0.35-0.45$ & $27.3 \pm 0.02$ & $1.70 \pm 0.02$ & $\begin{array}{l}\text { Second division of the two blastomers resulted in four } \\
\text { blastomeres. }\end{array}$ \\
\hline & $E$ & 1.10 & $27.3 \pm 0.02$ & $1.70 \pm 0.02$ & Eight blastomeres appearance. \\
\hline & $\mathrm{F}$ & 1.35 & $27.3 \pm 0.02$ & $1.70 \pm 0.02$ & Sixteen celled stage achieved. \\
\hline & G & 2.15 & $27.3 \pm 0.02$ & $1.70 \pm 0.02$ & Multiple cell formed. \\
\hline \multirow[t]{2}{*}{ Morula } & $\mathrm{H}$ & 4.20 & $27.3 \pm 0.01$ & $1.70 \pm 0.01$ & $\begin{array}{l}\text { Blastomere visible at the animal pole, which gradually } \\
\text { enlarged in size over time. }\end{array}$ \\
\hline & I & 8.0 & $27.5 \pm 0.02$ & $1.70 \pm 0.01$ & $\begin{array}{l}\text { Blastomeres gradually enlarged which started } \\
\text { invading the yolk by spreading over the yolk in the } \\
\text { form of a thin layer. }\end{array}$ \\
\hline \multirow[t]{2}{*}{ Gastrulation } & $\mathrm{J}$ & 9.3 & $27.5 \pm 0.02$ & $1.70 \pm 0.01$ & $\begin{array}{l}\text { Germinal ring visible, which occupied about half of } \\
\text { yolk by blastoderm. }\end{array}$ \\
\hline & $\mathrm{K}$ & 10.40 & $27.5 \pm 0.02$ & $1.70 \pm 0.01$ & $\begin{array}{l}\text { Blastoderm enveloped } 3 / 4 \text { th to the yolk. Embryo } \\
\text { shell visible. Appearance of optic rudiment. }\end{array}$ \\
\hline $\begin{array}{l}\text { Yolk plug } \\
\text { stage }\end{array}$ & $\mathrm{L}$ & 14.00 & $27.5 \pm 0.01$ & $1.70 \pm 0.01$ & $\begin{array}{l}\text { The yolk invasion developed and completed. } \\
\text { Rudimentary head and tail developed and become } \\
\text { differentiated. }\end{array}$ \\
\hline Organogenesis & M & $15.00-16.30$ & $27.0 \pm 0.01$ & $1.70 \pm 0.02$ & $\begin{array}{l}\text { Appearance of heart rudiment, pectoral fin buds and } \\
\text { gill rudiment. At this stage eye lack of pigment, the } \\
\text { notochord in cellular structure within } 16 \text { hours, when } \\
\text { auditory and optic vessels developed. }\end{array}$ \\
\hline $\begin{array}{l}\text { Just before } \\
\text { hatching }\end{array}$ & $\mathrm{N}-\mathrm{O}$ & $18.00-20.00$ & $27.0 \pm 0.02$ & $1.70 \pm 0.01$ & $\begin{array}{l}\text { Started of hatching, twisting movement and detached } \\
\text { from the yolk mass. Twisting movement become } \\
\text { more vigorous and the embryo ruptured the egg } \\
\text { capsule. }\end{array}$ \\
\hline
\end{tabular}

Multi celled stage: The more the cleavage occurred and the more the blastomeres developed. These cleavages enhanced the next cleavages. The sixteen celled stage in quick succession converted into $32,64,128$ cells stage and so on dividing geometrically. Because this was occurred so quickly that it was very difficult to observe or count all the cells. So, it was generally referred to as multi celled stage. Eggs measured at $1.70 \pm 0.02 \mathrm{~mm}$ (Fig. G). The temperature discloses a direct and linear role in the embryonic development of pangas fish larvae. The sixth cleavage (64 and 128 cell) stage was the first to occur along a latitudinal plane and had been seen within $2.15 \mathrm{hrs}$ of fertilization. Beyond the 
multicell stage, it becomes more difficult to discern any stereotypical array of blastomeres.

Morula stage: The blastomeres after repeated cleavage were resulted into morula stage within $4.20 \mathrm{hrs}$ after fertilization. A cap like structure was formed over the animal pole, which was gradually increased in size (Fig. H).

Early gastrula stage: The morula stage is first observed between 4.20 and 8.0 hrs. of fertilization. The blastomeres are distinctly divided to form many cells in the blastodisc in this stage. Within $4 \mathrm{hrs}$ of fertilization, the germinal ring (blastocoel) was formed by the invasion of the yolk sac. Gastrulation was resulted within $8.00 \mathrm{hrs}$ of fertilization. Eggs volume was measured at $1.70 \pm 0.01$ $\mathrm{mm}$ in diameter (Fig. I).

Middle gastrula stage: This stage was developed at $9.30 \mathrm{hrs}$ after fertilization. The formation of germinal ring around yolk was clearly visible and that about half of yolk was occupied by blastoderm. The diameter of the eggs was at $1.70 \pm 0.01 \mathrm{~mm}$ (Fig. J).

Late gastrula stage: In this stage, blastoderm covered $3 / 4$ th of the yolk and embryonic shield was clearly visible within $10.40 \mathrm{hrs}$. Optic rudiment was appeared. The diameter of the eggs was at $1.70 \pm 0.01 \mathrm{~mm}$ (Fig. K).

Yolk plug stage: In this stage, the yolk invasion completed by gradual spreading over the germ layer. Rudimentary head and tail was appeared and differentiated. It was seen within $14.00 \mathrm{hrs}$ after fertilization. It measured at $1.70 \pm 0.01 \mathrm{~mm}$ in diameter (Fig. L).

Organogenesis: The head and tail end of the embryo was distinguished (Fig. M). The embryo was elongated and encircled the yolk materials. Both tail and head ends were clearly differentiated and the beating heart was visible. Heart rudiment, pectoral fin buds, otocysts and gill rudiment were appeared stage by stage. The pectoral fin was appeared first of all the fins as a bud and then the fin rays were formed. At this stage eye lack of pigment, the notochord in cellular structure was visible within 15.00 to $16.30 \mathrm{hrs}$, when auditory and optic vessels were developed (Fig. N). Before hatching, the embryos try to rupture the perivitelline covering. The middle part of the embryo becomes disconnected from the egg covering by rupturing the egg capsule. In the successive periods, the egg membrane was broken down from the caudal region. Finally, the tail region of the hatchlings came out from the egg capsule with the body and head.

Hatching: The findings of larval development process of $P$. hypophthalmus at different stages were given below (Table 2): 
Hatching: Newly hatched larvae $(2.98 \pm 0.05 \mathrm{~mm})$ were slender, straight and transparent, gradually tapering towards the tail. Hearts of the larvae were functional in between head and the anterior margins of the yolk (Fig. 1 A).

Two hour post hatching: The length of the larvae was recorded at 3.20 \pm 0.05 $\mathrm{mm}$. The colour of larvae was yellowish-brown. Yolk sac was attached to the body. Melanophore bands became visible on posterior end of the body (Fig. 1B).

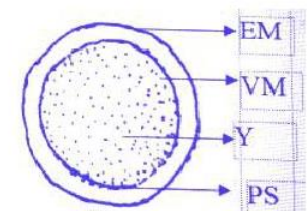

$\mathbf{A}$

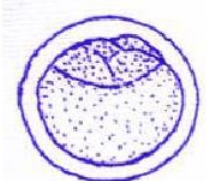

D

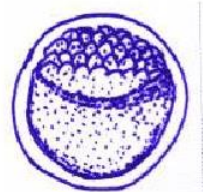

G

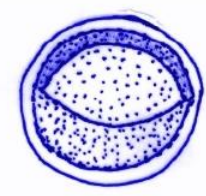

$\mathbf{J}$

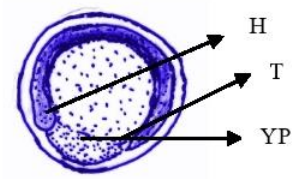

$\mathbf{M}$

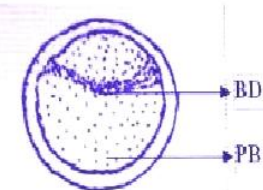

B

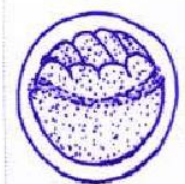

E

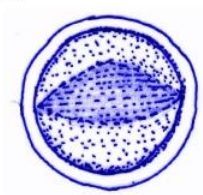

H

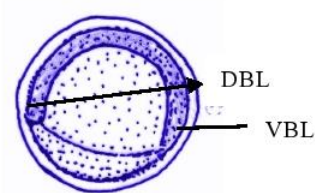

K

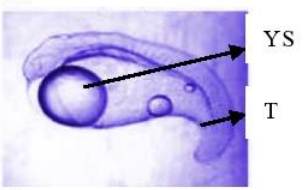

$\mathbf{N}$

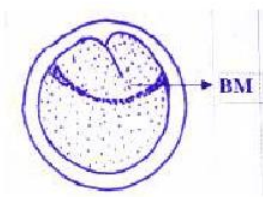

C

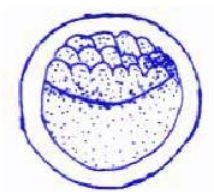

F

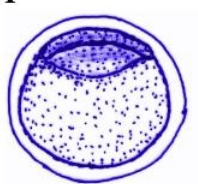

I

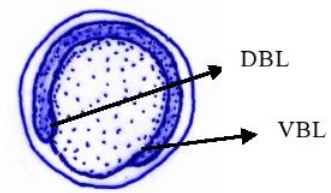

L

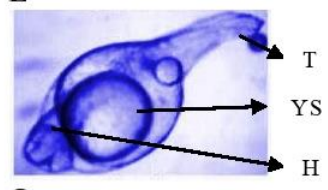

O

Fig.1, (A-P): A. Fertilized egg, B. Blastodisc just formed, C. Two celled stage, D. Four celled stage, E. Eight celled stage, F. Sixteen celled stage, G. Multi celled stage, H. Morola stage, I. Early gastrula stage, J. Middle gastrula stage, K. Late gastrula stage, L. Middle gastrula stage, M. Organogenesis, N. Hatching stage Plate, O. Just before hatching.NU=Nucleus, VM=Vitelline membrane, Y=Yolk, $\mathrm{EM}=$ Egg membrane, $\mathrm{PS}=$ Perivitelline space, $\mathrm{BD}=$ Blastodisc, $\mathrm{PB}=$ Periblast, $\mathrm{BM}=\mathrm{Blastomere}$, $\mathrm{DBL}=$ Dorsal blastophore lip, $\mathrm{VBL}=$ Ventral blastophore lip, $\mathrm{H}=$ Head, $\mathrm{T}=$ Tail, $\mathrm{YP}=$ Yolk plug, YS=Yolk sac. 
Four hour post hatching: The body was transparent. The yolk sac was partially decreased. Two vertical bands of melanophores were appeared at the posterior end. The total length was measured at 3.15 $\pm 0.05 \mathrm{~mm}$ (Fig. 1C).

Table 2. Summary of larval development process of $P$. hypothalamus

\begin{tabular}{|c|c|c|c|c|}
\hline $\begin{array}{l}\text { Stage } \\
\text { No. }\end{array}$ & $\begin{array}{l}\text { Age } \\
\text { (hrs) }\end{array}$ & $\begin{array}{l}\text { Figure } \\
\text { No. }\end{array}$ & $\begin{array}{l}\text { Mean total } \\
\text { length (mm) }\end{array}$ & Characteristics \\
\hline 1 & 0.00 & A & $2.98 \pm 0.05$ & $\begin{array}{l}\text { Larvae brown-yellowish in colour, Larvae slender, yolk } \\
\text { sac attached to the body. }\end{array}$ \\
\hline 2 & 2.00 & $\mathrm{~B}$ & $3.10 \pm 0.05$ & $\begin{array}{l}\text { Larvae colour is brown-yellowish, yolk sac still } \\
\text { remained attached to the body, melanophore bands } \\
\text { appeared on posterior end of the body and larvae } \\
\text { slender, transparent showing internal organs. }\end{array}$ \\
\hline 3 & 4.00 & $\mathrm{C}$ & $3.15 \pm 0.05$ & $\begin{array}{l}\text { Body of the larvae more transparent. Head and body } \\
\text { laterally compressed. Yolk sac partially reduced. }\end{array}$ \\
\hline 4 & 6.00 & $\mathrm{D}$ & $3.30 \pm 0.02$ & $\begin{array}{l}\text { Melanophores visible on the head, around the yolk sac. } \\
\text { The anterior part began to thickness. }\end{array}$ \\
\hline 5 & 8.00 & $\mathrm{E}$ & $3.40 \pm 0.01$ & $\begin{array}{l}\text { The yolk sac partially decreased. The tail thickened and } \\
\text { melanophores distribution no change. }\end{array}$ \\
\hline 6 & 10.00 & $\mathrm{~F}$ & $3.50 \pm 0.09$ & $\begin{array}{l}\text { A tubular pulsating heart visible. Yolk sac decreased. } \\
\text { Eye and anus slightly visible. Intestine also comes into } \\
\text { view. }\end{array}$ \\
\hline 7 & 12.00 & $\mathrm{G}$ & $3.60 \pm 0.05$ & $\begin{array}{l}\text { Vertical melanophore bands very prominent. } \\
\text { Chromatophores visible in the eye only. Ventral } \\
\text { embryonic fin fold more prominent. Pectoral fin bud } \\
\text { appeared. }\end{array}$ \\
\hline 8 & 16.00 & $\mathrm{H}$ & $3.80 \pm 0.02$ & $\begin{array}{l}\text { Interior part of the yolk globular in shape. Pectoral fin } \\
\text { rudiment faintly visible. }\end{array}$ \\
\hline 9 & 20.00 & I & $4.10 \pm 0.02$ & $\begin{array}{l}\text { Newly chromatophores appeared above eyes. Yolk sac } \\
\text { became thin. }\end{array}$ \\
\hline 10 & 24.00 & $\mathrm{~J}$ & $5.45 \pm 0.01$ & $\begin{array}{l}\text { Operculum appeared but did not expand over gills. } \\
\text { Dark eyes pigmented. Myomeres partially visible. } \\
\text { Prominent pectoral and pelvic fins fold. Air bladder } \\
\text { visible and anal distinct. Myomere slightly visible. }\end{array}$ \\
\hline 11 & 32.00 & K & $5.50 \pm 0.01$ & $\begin{array}{l}\text { Myomeres appeared. Colour of the larvae altered to } \\
\text { silver-yellowish, Mouth cleft formed. }\end{array}$ \\
\hline 12 & 36.00 & $\mathrm{~L}$ & $5.56 \pm 0.04$ & $\begin{array}{l}\text { The eyes increased in size and pigmented. Pectoral fin } \\
\text { and mouth cleft more prominent. Dorsal and ventral } \\
\text { sides of the larvae pale yellow. Brain lobe visible. }\end{array}$ \\
\hline 13 & 40.00 & M & $6.0 \pm 0.02$ & $\begin{array}{l}\text { Pectoral fin fold well developed. Mouth cleft bscame } \\
\text { more prominent. The eyes increased in size and densely } \\
\text { pigmented with reddish colour. }\end{array}$ \\
\hline 14 & 44.00 & $\mathrm{~N}$ & $6.10 \pm 0.01$ & $\begin{array}{l}\text { Yolk sac convex interiorly. A few black Chromatophores } \\
\text { appeared in a row from the area posterior up to the } \\
\text { base of the caudal fin. Opercula fold visible. Brain lobe } \\
\text { clearly and mouth cleft easily distinguished. The heart } \\
\text { started to function actively. }\end{array}$ \\
\hline 15 & 48.00 & $\mathrm{O}$ & $6.20 \pm 0.02$ & $\begin{array}{l}\text { Eyes fully became pigmented. Pectoral fin bud more } \\
\text { pronounced. The jaws more pigmented. Air bladder } \\
\text { distinct. Large black chromatophores appeared on } \\
\text { head. Gills prominent and air bladder elliptical in size. } \\
\text { Brain lobe fully visible. Yolk sac completely vanished } \\
\text { and larvae started feeding. }\end{array}$ \\
\hline 18 & 72.00 & $\mathrm{R}$ & $7.20 \pm 0.02$ & $\begin{array}{l}\text { Myomere clearly visible. The larvae were silver-blackish } \\
\text { and transparent in colour. Larvae swim actively. }\end{array}$ \\
\hline
\end{tabular}


Six hour post hatching: Melanophores was visible on the head, around the yolk sac or on the yolk sac. The anterior part was begun to thicken. The colour of the yolk sac was brown-yellowish. The total length was measured $2.7 \pm 0.02$ $\mathrm{mm}$ (Plate 35.1D).

Nine hour post hatching: The yolk sac was moderately reduced. Melanophores become visible and more prominent. The length of the larvae was at $3.30 \pm 0.01$ $\mathrm{mm}$ (Fig.1E).

Eleven hour post hatching: A tubular pulsating heart appeared. Eye and anus become slightly visible. Intestine was appeared and visible. Notochord was visible. The length of the larvae was at $3.50 \pm 0.09 \mathrm{~mm}$ (Fig. 1F).

Thirteen hour post larvae: Pectoral fin bud became visible. Melanophore bands were very much prominent at the posterior end of the body. A large number of melanophores also appeared above the eye and around the yolk sac. The lengths of the larvae were increased to $3.60 \pm 0.05 \mathrm{~mm}$ in size (Fig. $1 \mathrm{G}$ ).

Seventeen hour post larvae: Melanophore appeared on the head and body. Brain did not distinguish from the body. Yolk sac slightly reduced. Myomere were still partly visible. The length of the larvae was at 3.80 $\pm 0.02 \mathrm{~mm}$ (Fig. $1 \mathrm{H}$ ).

Twenty one hour post hatching: The total length of the larvae measured at $4.1 \pm 0.02 \mathrm{~mm}$. The eyes were partially pigmented. External melanophores became visible dorsally on head. Myomeres were partially visible. The yolk sac decreased and became thin (Fig. 1I).

Twenty five hour post hatching: Chromatophores became visible in the head and above the eyes. Eyes were pigmented and dark in colour. Pectoral and pelvic fin bud was appeared. Air bladder became visible. Anal was distinct. Myomere became partially visible. The size of the larvae was recorded to $5.45 \pm 0.01 \mathrm{~mm}$ in size (Fig. $1 \mathrm{~J}$ ).

Thirty three hour post hatching: Myomeres were visible. Colour of larvae turned was varied to silver-yellowish. Mouth cleft was formed. At this stage, the length of the larva was recorded to $5.50 \pm 0.01 \mathrm{~mm}$ in size (Fig. $1 \mathrm{~K}$ ).

Thirty seven hour post hatching: At this stage, the length of the larva was $5.60 \pm 0.04 \mathrm{~mm}$. The pectoral and pelvic fin buds were visible. The colour of the larvae was whitish-black. Eyes became whitish black (Fig. 1L).

Forty one hour post hatching: Eyes were increased in size and became densely pigmented. Brain lobe was visible. Pectoral and pelvic fin fold were developed. Myomeres were partially visible. At this stage, the length of the larva was $6.00 \pm 0.09 \mathrm{~mm}$ (Fig. 1M).

Forty three hour post hatching: Opercula fold was come into view. Brain lobe clearly visible and mouth cleft easily differentiated. The heart was functioned actively. Upper and lower jaws were fully formed. The larvae were increased to $6.10 \pm 0.01 \mathrm{~mm}$ in size (Fig. N). 

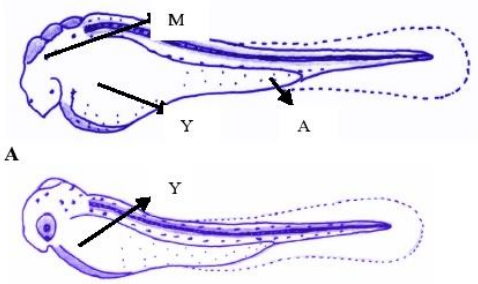

C
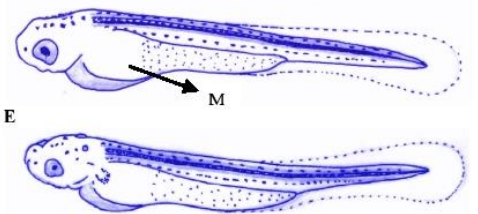

G
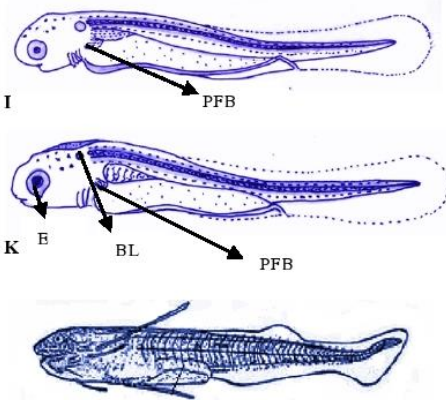

M

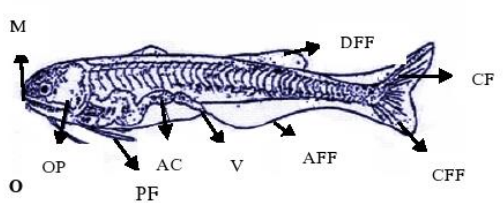

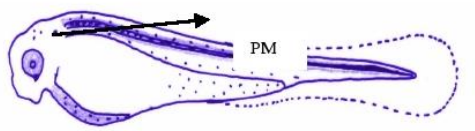

B
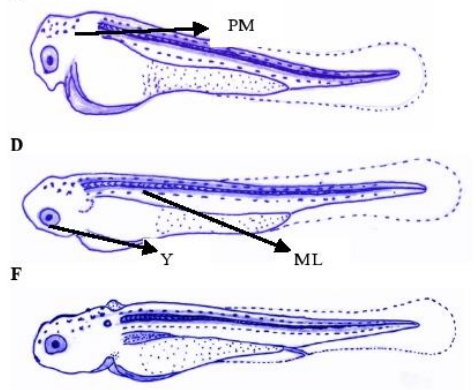

H

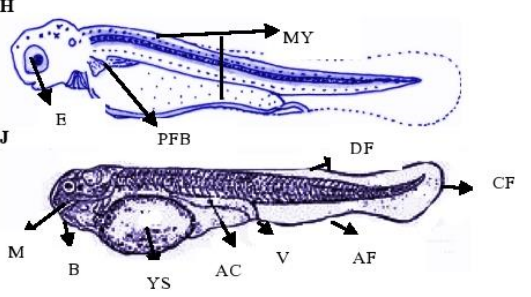

L
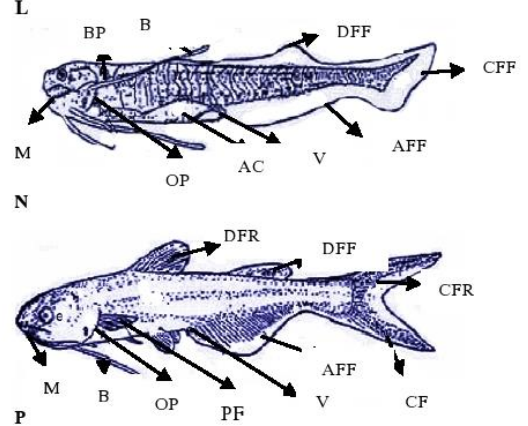

Fig. 2. A. Zero hour old larvae, B. Two hrs old larvae, C. Four hrs old larvae, D. Six hrs old larvae, E. Nine hrs old larvae, F. Eleven hrs old larvae, G. Thirteen hrs old larvae, H. Seventeen hrs old larvae, I. Twenty one hrs old larvae, J. Twenty five hrs old larvae, K. Thirty three hrs old larvae, L. Thirty seven hrs old larvae, M. Forty one hrs old larvae, N. Forty three hrs old larvae, O. Forty six hrs old larvae, P. Seventy two hrs old larvae.

$\mathrm{M}=$ Melanophore, $\mathrm{Y}=\mathrm{Yolk}, \mathrm{PM}=$ Prominent melanophore, $\mathrm{E}=\mathrm{Eye}, \mathrm{BL}=\mathrm{Brain}$ lobe, $\mathrm{MC}=\mathrm{Mouth}$ cleft, $\mathrm{M}=$ Mouth, $\mathrm{B}=$ Burble, $\mathrm{V}=$ Vent, $\mathrm{AC}=$ Alimentary canal, $\mathrm{OP}=$ Operculum, $\mathrm{BP}=\mathrm{Body}$ pigmentation, $Y S=Y o l k$ sac, $D F F=$ Dorsal fin fold, $D F R=$ Dorsal fin ray, $C F=$ Caudal fin, $C F F=$ Caudal fin fold, $\mathrm{CFR}=$ Caudal fin ray, $\mathrm{AFF}=\mathrm{Anal}$ fin fold, $\mathrm{AFR}=$ Anal fin ray. $\mathrm{PF}=$ Pectoral fin, $\mathrm{PFB}=\mathrm{Pectoral}$ fin bud.

Fifty six hour post hatching: Air bladder was distinct. Eyes became fully pigmented. Pectoral fin bud was more pronounced. A few black chromatophores 
were found in a row from the posterior to the auditory concentrations up to the base of the caudal fin. Large black chromatophores were visible on the head. The length of the larvae was increased to $6.20 \pm 0.02 \mathrm{~mm}$ in size (Fig. 1O).

Seventy two hour post hatching: The larvae were increased to $7.20 \pm 0.09 \mathrm{~mm}$ in length. The brain lobe was fully visible. Yolk sac was completely disappeared and larvae started feeding. Gills became prominent. Air bladder was elliptical. Prominent large black chromatophores were visible on the head. Notochord was in an upward position only at the very terminal past. Pectoral fin folds was distinct and rudimentary rays was built up in caudal fins (Fig. 1P).

The character of fertilized eggs was round, transparent, demersal and adhesive. The colour of the fertilized eggs was greenish or yellowish brown. The egg capsule and yolk sphere were yellowish brown in color. Mookerjee and Mazumder (1950) found that more or less yellowish brown colour eggs were found in case of Clarias batrachus. Fertilized eggs of $P$. hypothalamus were measured between the diameters of the yolk ranges from $1.0-1.7 \mathrm{~mm}$. In comparison, the length and diameter of fertilized eggs of pangas are larger than other native catfishes. Whereas, Channel catfish (Ictalurus punctatus) eggs average 3.5-4.0 $\mathrm{mm}$ in diameter before they are laid (Scott and Crossman 1998) and Heteropneustes fossilis are 1.0 $-1.2 \mathrm{~mm}$ in diameter (Bhargava 1970) and the diameter of the yolk of Clarias gariepinus is $0.6-0.8 \mathrm{~mm}$ (Zaki and Abdulla 1984). Embryonic developmental stages of $P$. sutchi are shorter $(24-36 \mathrm{hrs})$ in relation to temperature. But in case of early embryonic development of C. gariepinus requires $21-26 \mathrm{hrs}$ at $20-32^{\circ} \mathrm{C}$ (Bruton 1979a).

The morula stage of pangas showed between 2.1-4.0 hrs after fertilization. Different catfish have different time period for the morula stage. According to Bruton (1979a), the African catfish (C. gariepinus) reaches morula stage within $3.3 \mathrm{hrs}$ of fertilization and in case of Heteropneustes fossilis reaches within 1.5 hrs (Thakur et al. 1974). Chakraborty et al. (2007) found that the Sarpunti (Puntius sarana) attains morula stage within $4.20 \mathrm{hrs}$ of fertilization. Within 4$16 \mathrm{hrs}$ of fertilization, the blastula stage, yolk plug stage, indication of embryonic shield (after $8 \mathrm{hrs}$ ), head, tail end and somite formation (after $10.40 \mathrm{hrs}$ ), movement of the caudal region (after $12 \mathrm{hrs}$ ) and body segmentation (after $16 \mathrm{hrs}$ ) of the pangas embryo was recorded. The embryo showed twisting movement inside the egg shells 1-3 hrs before hatching. The protruding embryo violently was beat inside the egg shell and tried to rupture the perivitelline covering within $1 \mathrm{hr}$ of hatching. A similar study was found in case of H. fossilis (Thakur et al. 1974) and C. batrachus (Thakur 1980).

The newly hatched pangas larvae came out from the eggshell covering with their lengths ranging from $2.98-3.10 \mathrm{~mm}$. According to Peteriand Nandi (1992); and 
Mookerjee and Mazumder (1950), the newly hatched C. gariepinus larvae measured from 3.4-4.0 $\mathrm{mm}$ and C. batrachus were $5.80 \mathrm{~mm}$ in length. The yolk sac of pangas larvae was fairly well absorbed by 3 days of hatching. Newly hatched larvae strongly received the supplementary food within 3-6 days of hatching because of their cannibalistic character. This characteristic is also found in C. gariepinus (Peteri et al. 1992), African catfish (Zaki and Abdulla 1984) and cod (Gadusmorhua) juveniles (Folkvord 1991).

The two days old pangas larvae were measured at least $3.10 \pm 0.05 \mathrm{~mm}$ in length. Larvae of pangas were active and well developed in body shape and form. Thread like elongated barbules became distinct during this stage. Aerial respiration of the fry was created after the 8-10 days of hatching. Peteri et al. (1992) found this type of phenomenon in the case of C.gariepinus, but its accessory respiratory organ is not active before $12-14$ days post hatching. The larvae and fry of pangas were active and rapid by 5 days and afterwards because of intensive development. During the present research the embryonic and larval development of pangas were calculated at an ambient temperature of 26.5 to $27.5^{\circ} \mathrm{C}$. The rate of development of the larvae variation seems to be temperature dependent factor. The higher the temperature the quicker was the development (Hoar and Randal 1969; Chakraborty et al. 2007).

\section{CONCLUSION}

The embryonic and larval developmental stages of $P$. hypothalamus shows a significant and rhythmic development. Cannibalism is a common criterion of catfish, which also exhibits in pangas larvae when food is insufficient. Temperature is inversely related to the incubation and hatching periods of pangas. The notochord is gradually extended up to the caudal region of the hatchlings by the seventh day of successive developmental periods. Considering all the facts and findings of the experiment the present stprovides information on early development stages of the P.hypophthalmus. The present study was generated some information on the early life history, developmental stages and commencement of first feeding time for larval rearing. This study will be helpful to the fishery biologists in understanding on the biology and ecology of the fish, which might be of great opportunity to take appropriate measure for sustainable culture and management technology of pangas.

Acknowledgements: The author very much thankful to owner of Satota hatchery, Mymensingh for his technical and financial support of the study. 


\section{LETERATURE CITED}

ARIFIN, Z. 1990. Rearing of patin fry (Pangasiuspangasius HB) in different salinities. Bull. PenelitianPerikanan Barat (Indonesia). 9 (1): 43- 51.

ASIFUL, I. 2005. Embryonic and early development of Thai pangas (Pangasiussutchi Fowler, 1937).Dev. growth Differ.47:1-6.

BARDACH, J. E., RYTHER, J. H. AND MELARNEY, W.O. 1972. Aquacuture- the Farming and Husbandry of Fresh Water and Marine Organisms. Wiley Inter Science, New York.

BHARGAVA, R. M. S. 1970. The fecundity of Heteropneustesfossilis (Bloch). Bombay Nat. Hist. Soc. 67: 583 - 588.

BRUTON, M. N. 1979a. The breeding biology and early development of Clariasgariepinus (Pisces: Clariidae) in lake Sibaya, South Africa with a review of breeding in species of subgenus Clarias (Clarias). Trans Zool. Soc. Lond. 35:1-45.

CHAKRABORTY, B.K., MIAH, A., HABIB, M.A.B. AND MIRZA, J.A. 2007.Embryonic and larval development of indigenous sarpunti, Puntiussarana (Hamilton). Bangladesh J. Zool. 35(1): 141-151.

DAVID, A. (1962) Brief taxonomic account of the GangeticPangasiuspangasius (Ham.) with description of a new sub-species from the Godavari. Proc. Indian Acad. Sci. 34(3): 136-156.

FOLKVORD, A. 1991. Growth, survival and cannibalism of cod juveniles (Gadusmorhua): Effect of feed type, starvation and fish size. Aquaulture. 97: 41-59.

HOAR, W. S. AND RANDALL, D. J. 1969. Reproduction and Growth Bioluminescence, Pigments, and Poisons.Fish Physiology.3: 1-485.

KHAN, H. A. 1972.Induced breeding of air breathing fishes.Central International Fish Res. Institute Barrackpore.Indian farming.Indian Council of Agricultural Res. KrishiBhavan. B. O, no. 522672. New Delhi.

MANAT, C., SURAPHONG, W., SANGA, L. 1990. Breeding of Chao Phya Giant catfish, Pangasiussanitwongsei. Thai- Fish Gazette. 43 (2): 95- 97.

MOOKERJEE, H.K., MAZUMDER, S.R. 1950. Some aspects of the life history of Clariusbatrachus Linn. Proc. Zool. Sci. Bengal 3 (2):119- 153.

OKOMODA, V.T., CHUKOH, I.V., HUSSAN, A., AMORNSAKUN, T., SHERIFF, S.M. 2017.Performance and characteristics of the progenies from the reciprocal crosses of Pangasianodonhypophthalmus (Sauvage, 1878) and Clariasgariepinus (Burchell, 1822).Aquaculture. 489:96-104. DOI: 10.1016/j.aquaculture.2018.02.011

PETRI, A. AND NANDI, S. 1992. Induced breeding and fry rearing techniques of African catfish.BGD. 87/045 (91), 5.

ROBERTS, T. R. AND VIDHAYANON, C. 1991.Systematic revision of the Asian catfish family Pangasiidae, with biological observation and descriptions of three new species.Proc.Acad. Nat. Sci. Philad. 143: 97-144. 
SCOTT, W. B. AND CROSSMAN, E. J. 1998. Freshwater Fishes of Canada. Galt House Publications Ltd. Oakville, Ontario.

THAKUR, N. K. 1980. Notes on the embryonic and larval development of an air breathing cat fish, Clariasbatrachus (Linn.). J. Inand. Fish.Soc. India. 12:30- 45.

THAKUR, N. K., PAL, R. N. AND KHAN, H. A. 1974. Embryonic and larval development of HeteropneustesFossilis (Bloch). J. Inl. Fish.Soc. India. 6: 33- 44.

WANPEN, M. 1984. Taxonomical and behavioral difference of PlaBuk, Pangasiandongigas Chevy and PlaSwai. Pangasiussutchi Fowler fingerling. Department of Fish Bangkok, Thailand. 12.

ZAKI, M. I. AND ABDULLA, A. 1984. The reproduction and development of Clariasgariepinus from Lake Manzula (Egypt). J. Ichthyol. 23 (6):48- 58.

ZULKAFLI, A. R. AND ZAHARI, A. 1989.The supply of food and culture techniques of PangasiusSutchi Fowler in floating net cages. Fisheries Research Seminar, IPP, Penang, Malaysia, pp. 78- 85 .

(Manuscript received on 15 March 2021 revised on 15 April 2021) 